\title{
Participatory Conservation of Sacred Natural Sites: A Study of Haritha Poonkavanam Project of Sabarimala, Kerala, India
}

\author{
R. Kamalahar \\ Research Scholar, Department of Political Science and Development Administration, Gandhigram Rural \\ Institute-Deemed to be University, Gandhigram -624302, Tamil Nadu, India
}

\begin{abstract}
Biodiversity and the environment are inextricably linked to human cultural diversity. Traditional cultures have frequently preserved or kept untouched portions of their natural surroundings. Most of these civilizations regard some locations as holy, prohibiting most or all human activities. As evidenced by the sacred mountain environment and sacred vegetation, traditional culture plays an important role in biodiversity conservation. Sacred forests are part of a long-standing practise of protecting certain geographical regions with cultural and religious importance. A number of studies have shown that sacred forests are significant refuges for biological variety, particularly medicinal plants, amid highly anthropogenic environments, in addition to their cultural value. While sacred natural sites have been effective conservation sites in the past, there are various dangers to these ecosystems now, ranging from demands for the use of timber and other forest products to agricultural clearance and general changes in cultural practises as well pilgrimage to these sacred areas. The significance of natural sacred sites, particularly sacred groves, is gaining attention in international conservation organisations such as UNESCO and the IUCN, and has significant implications for the implementation of Article 8j of the Convention on Biological Diversity, which emphasises the utilisation of traditional knowledge and practises for conservation and long-term usage.
\end{abstract}

Key words: Sacred natural sites, Cultural diversity, Biological diversity, Vana Samrakshana Samithi

\section{INTRODUCTION}

Natural features or regions of land or water that have unique spiritual importance to peoples and communities are known as sacred natural sites (Wild and McLeod, 2008).Sacred natural places are found in most nations and appear to be among the world's oldest and most venerated locations, while new sacred nature sites are still being built, often by migration to other nations. Sacred natural places include areas considered sacred by indigenous and traditional peoples, as well as areas designated as places of worship and remembrance by religions or faiths. The explicit and often comprehensive protection of wild species in sacred natural areas and seminatural environments around religious buildings has an impact on biodiversity conservation. The world's earliest form of habitat preservation is probably definitely sacred natural locations. While some sacred natural places are located within official protected areas, many thousands more exist in many nations across the world as a largely unacknowledged "hidden" conservation network that can be more rigorously maintained than national parks. Sacred natural places, which generally harbour significant biodiversity and preserve vital ecosystems, have been identified and protected as one of the most prominent types of culture-based conservation. Traditional sacred natural places serve the same purpose as legally protected regions in many civilizations. 
Because of the spiritual significance of these places, access and usage are typically restricted, and many of them are left in their natural or near-natural state. While many sacred places are only visited on a limited basis, others are visited on a regular basis. During pilgrimages, some attract enormous crowds of thousands, if not millions, of people (Motonaka, 2006; Wickramasinghe, 2005).

Human disturbance has been limited or eliminated, or rigorous management has been implemented, typically over extended periods of time, resulting in high biodiversity levels. The multitude of diverse human civilizations that care for and hold them sacred is linked to such biological diversity (Verschuuren et al., 2010). Human impact is stronger in some sacred natural places, and these areas may be semi-natural or even substantially changed, but frequently in ways that maintain high biodiversity levels. Indigenous, local, and mainstream cultures and spiritual traditions, each with their own worldviews, created protected areas which are now vulnerable to a variety of external and internal pressures and threats, including illegal timber and wildlife extraction, impacts from extractive industries operations, encroachment by outsiders, disrespectful tourism, poverty and population dynamics, and environmental degradation. The Convention on Biological Diversity, adopted at the Rio de Janeiro Earth Summit in 1992, emphasized the importance to maintain and encourage indigenous cultural traditions that are compatible with conservation or sustainable use requirements when it comes to biological resources (Article 10). Several worldwide conferences on the issue have since been held, notably the 1998 UNESCO symposium on "Sacred Sites, Cultural Diversity, and Biological Diversity." They reflect a growing appreciation for the importance of sacred sites as element of protected area networks.

\section{Research Problem}

Religious beliefs are significant components of culture, and all of the world's great religions value biodiversity and the natural environment (Hamilton 1993; Puspa 1996; David et al 1998; McNeely 2000). The "Guidelines for Guardians of Protected Areas on Sacred Natural Sites," published by the IUCN and UNESCO in 2008, laid out the essential principles for managing sacred natural sites. They are completely relevant to sacred sites that are part of World Heritage Sites.

1. Sacred natural places that are currently within protected areas (PA) should be respected. This adds dimension to the principles expressed on the site.

2. Sacred natural sites are getting included into design and policy programmes in protected areas. This integration must be done in a private manner, and it must be incorporated into planning, zoning, restoration programmes, ecological and landscape methods, and governance.

3. Stakeholder consent, involvement, inclusion, and cooperation are encouraged, with specific attention paid to prior consent, voluntary engagement, inclusivity, and legitimacy, as well as dispute resolution methods.

4. Encouragement of better understanding and knowledge of sacred natural places, with a focus on public awareness, multicultural discussion, inventorying, and a multidisciplinary, holistic qualitative research approach and networking.

5. Sacred natural sites are protected while proper management access and usage is provided. To contrast, the idea of "access and usage" incorporates visitor demands as well as protection and decision-making control. It also includes concerns such as cultural usage, finance, and development constraints.

6. Honouring the interests of sacred natural site protectors within a national strategic framework that incorporates institutional and legal safeguards as well as a rightsbased approach. The affirmation of 
tenure and the rights of caretakers are also important aspects of this notion

The Sabarimala Temple has been a prominent pilgrimage site in India throughout the years. The ecosystem is put under great strain when a big number of people congregate in a small location inside the forest for a short span of time. The collection of wood products from the forest, cutting poles for constructing sheds, improper waste disposal of biodegradable plastic waste, attempting to create trekking tracks through trampling tends to result in soil degradation, lighting at night during trekking to the temple, temporary tents, and halting places are all major hazards caused by pilgrim movement. Furthermore, all pilgrims are expected to take a bath in the sacred river Pamba. The coliform bacteria level in the Pampa River was estimated to be in the range of three lakhs per $100 \mathrm{ml}$ in investigations performed by the Kerala State Pollution Control Board (KSPCB), although the highest allowed limit of coliform count is $500 \mathrm{mpn}$ per $100 \mathrm{ml}$ of water. During the festival period, the river water is contaminated with waste products and sewage to such an alarming degree that it is unsuitable for bathing, according to the Central Pollution Control Boards (CPCB) regulation.

Solid waste brought in by travellers during festival season, such as polythene covers and polythene bottles, causes environmental concerns and puts wild animals in danger. The forests are home to a variety of wild creatures, including elephants, Gaurs, Nilgiri Langurs, and other primates. These animals ingest the plastic trash, causing indigestion and, eventually, death. Huge heaps of garbage in the bodies of elephants and primates, including polythene bags, aluminium foil, and wrappers, were discovered during postmortem examinations. The pollutants load on the Pampa River has increased as a result of inappropriate garbage disposal. The concentration of a huge number of people in a small location within the reserve forest for a short period of time places great strain on the ecosystem, particularly on the Pampa River's water quality.

Tribal tribes are the most forestdependent groups, and they earn money through collecting food, fuel wood, fodder, and other non-timber forest products, among other things. People's livelihood concerns were reduced to a secondary position in the course of forest conservation, and people's participation in protecting resources and active involvement were relegated to a secondary position.

This would be a huge step forward in human evolution if a system could be developed to harness this resource to encourage pilgrims and pilgrim sites throughout the world to become examples of environmental sustainability and leave a good impact on the Earth. It was critical to build a grassroots campaign to eliminate plastic pollution by educating and mobilising enthusiasts and forest-dependent communities. The Kerala Forest Department's Ranni Forest Division devised this wonderful concept, which was given a structural framework through the Green Poonkavanam project.

\section{Objectives}

1. To prevent, minimize and abate impacts of Environmental pollution from point and non-point sources on various components of biological diversity, by better environmental governance, Pollution and Waste management and Restoration of Degraded System

2. Creating alternative sustainable livelihoods to the forest dependent communities by involving them in the Eco development and environmental Conservation activities.

3. Conservation of floral and faunal biodiversity and sustainable use biodiversity resources.

\section{Study Area}

Sabarimala, situated in Perinadu village in Ranni Taluk in Kerala's Pathanamthitta District, is the world's largest sacred landscape, with millions of 
worshippers flocking to the temple every year. After defeating the mighty monster Mahishi, the Hindu God Ayyappan is said to have meditated in Sabarimala. The temple, which is located on a mountaintop surrounded by mountains and lush forests, is open during the festival season, which spans from November 15th to January 14th each year. Sabarimala temple is situated on the banks of the Pamba River, which originates in the Western Ghats in Sabari Hills and streams for 179 kilometres through the districts of Idukki, Pathanamthitta, and Alappuzha before merging the Vembanad Lake.

Many sacred natural places have high biodiversity; these biodiversity levels are typically substantially greater than in regions nearby where habitats have been extensively changed by various forms of land use; and these biodiversity levels are often higher than in identical habitat types located nearby (Tiwari et al., 1998)

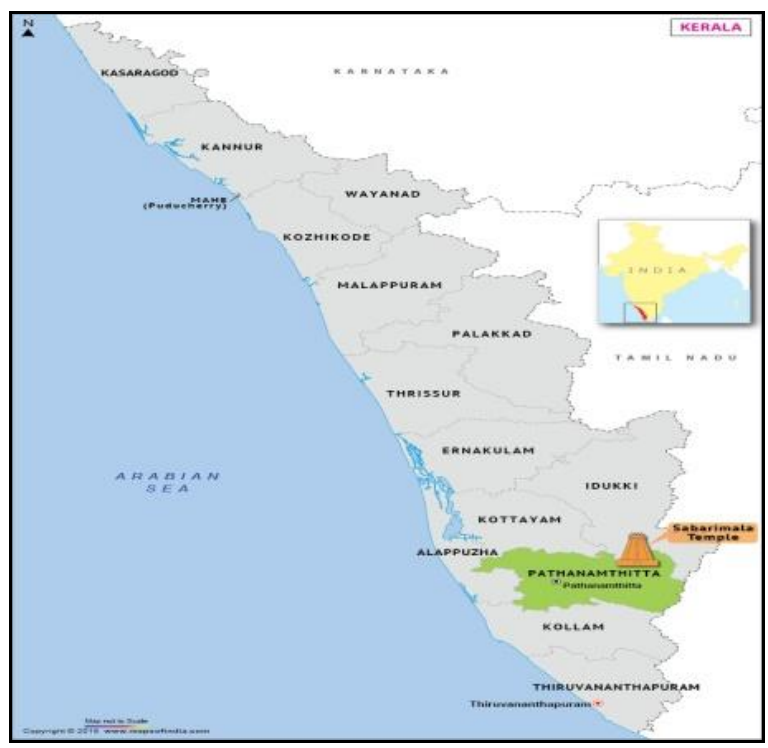

\section{Stake Holders}

\begin{tabular}{|c|c|c|c|c|c|c|c|c|}
\hline \multicolumn{9}{|c|}{ VSS WISE DETAILS OF RANNI FOREST DEVELOPMENT AGENCY } \\
\hline \multirow{2}{*}{ Sl.No } & \multirow{2}{*}{ Range } & \multirow{2}{*}{ Name of VSS } & \multirow{2}{*}{ Fringe/Tribal } & \multirow{2}{*}{ Reg.No } & \multirow{2}{*}{ Management Area (Ha) } & \multicolumn{3}{|c|}{ Family details (No) } \\
\hline & & & & & & Sc & ST & Others \\
\hline 1 & \multirow{16}{*}{ 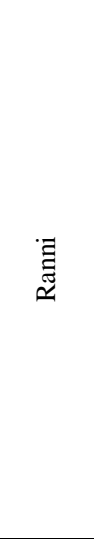 } & Nellimala & Fringe & $511-7 / 2001$ & 200 & 3 & & 94 \\
\hline 2 & & Kurmbanmoozhy & Fringe & $511-4 / 2000$ & 200 & 24 & 89 & 42 \\
\hline 3 & & Laha & Fringe & $511-5 / 2000$ & 200 & 20 & 44 & 93 \\
\hline 4 & & Kariyamplavu & Fringe & $511-12 / 2002$ & 150 & 6 & & 60 \\
\hline 5 & & Mothiravayal & Fringe & $511-10 / 2001$ & 100 & 39 & 161 & \\
\hline 6 & & Valiyakavu & Fringe & $511-1 / 1999$ & 150 & 19 & & 126 \\
\hline 7 & & Adichipuzha & Fringe & $511-13 / 2002$ & 100 & & 200 & \\
\hline 8 & & Kudamurutty & Fringe & $511-11 / 2001$ & 150 & 7 & 47 & 128 \\
\hline 9 & & velanplavu & Fringe & $511-2 / 2000$ & 125 & 17 & 38 & 7 \\
\hline 10 & & Kochethupara & Fringe & $511-18 / 2004$ & 100 & 7 & & 74 \\
\hline 11 & & Moonnukallu & Fringe & $511-9 / 2001$ & 200 & 8 & 4 & 130 \\
\hline 12 & & Arayanjilimon & Fringe & $511-8 / 2001$ & 150 & 13 & 76 & 122 \\
\hline 13 & & Manakkayam & Fringe & $511-6 / 2001$ & 200 & 2 & 54 & 28 \\
\hline 14 & & Bimmaram & Fringe & $511-3 / 2000$ & 150 & & & \\
\hline 15 & & Chollanavayal & Fringe & $511-14 / 2002$ & 100 & & 40 & \\
\hline 16 & & Naranamthodu & Fringe & $511-15 / 2002$ & 200 & 28 & 6 & 92 \\
\hline 17 & \multirow{3}{*}{ 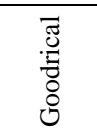 } & Kochukoickal & Fringe & $513-4 / 2001$ & 150 & 0 & 0 & 116 \\
\hline 18 & & Angammoozhi & Fringe & $\begin{array}{l}513-2 / 2001 \\
17-10-2001\end{array}$ & 200 & 28 & 1 & 189 \\
\hline 19 & & Chippenkuzhi Moozhiyar & Tribal & $5134 / 2009$ & 4000 & & 27 & 27 \\
\hline 20 & \multirow{11}{*}{ 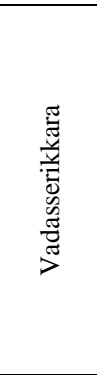 } & Kattachira & Fringe & $512-2 / 2001$ & 150 & 49 & 0 & 31 \\
\hline 21 & & Pampini & Fringe & $512-3 / 2001$ & 100 & 12 & 89 & 69 \\
\hline 22 & & Kodumudi & Fringe & $512-5 / 2001$ & 150 & 2 & 90 & 46 \\
\hline 23 & & Kodumudi-Karikayam & Fringe & $512-10 / 2004$ & 100 & 35 & 7 & 70 \\
\hline 24 & & Olikallu & Fringe & $512-1 / 2001$ & 100 & & 11 & 49 \\
\hline 25 & & Mekkannam & Fringe & $512-14 / 2004$ & 300 & 4 & & 62 \\
\hline 26 & & Monpilavu & Fringe & $512-8 / 2002$ & 250 & 23 & 0 & 92 \\
\hline 27 & & Villoonnippara & Fringe & $512-9 / 2002$ & 200 & 30 & 1 & 119 \\
\hline 28 & & Thannithodu & Fringe & $512-4 / 2001$ & 100 & 59 & 19 & 173 \\
\hline 29 & & Gurunathanmannu & Fringe & $512-6 / 2001$ & 200 & 25 & 0 & 91 \\
\hline 30 & & Koothadimon & Fringe & $512-13 / 2004$ & 250 & 3 & 0 & 46 \\
\hline
\end{tabular}

Identifying and engaging with custodians of sacred natural sites requires a great level of understanding, respect, and mutual trust, particularly when dealing with historically challenging, politically significant, and contentious situations. 
Individuals or organisations wanting to be recognised as caregivers must establish their legitimacy, and in certain cases, their authenticity. The Poonkavanam forests are home to a diverse range of stakeholders, the most prominent of which are the tribes. The Department Of tourism, Devaswam Board of Travancore, Ayyappa Pilgrims who visit the Sabarimala Temple, and Vana Samrakshana Samithi (VSS) of the Forest Department are the primary stakeholders, as are underprivileged labourers and small land owners.

Forest conservation with the help of forest-dependent communities, known as Joint Forest Management, was envisioned in the 1988 National Forest Policy (JFM). Participatory forestry management (PFM) establishes forest protection, manages noonwood resources with the help of local people, and secures local people's living income. One of the goals of participatory forest management (PFM) is to improve tribal welfare and establish a sustainable livelihood mission. The Vana Samrakshana Samithi (VSS) is a village-level organisation that works under the Participatory Forest Management system (PFM). People who live near forests form the Vana Samrakshana Samithi (VSS), and the forest department administers different initiatives connected to forest conservation with their participation.

\section{RESULTS AND DISCUSSION}

The Green Poonkavanam project's major activities included

\section{Awareness campaign}

Department employees, Vana samrakshana samiti (VSS-JFMC) members, school and college students, and local forest-dependent populations were all educated about the need of keeping Pampa and reserve forest areas pollution-free. Workshops for departmental employees and VSS members, presentations to school and college students and youth groups, a Pampa Padayatra with the assistance of locals, a Motor Rally, and a participative meeting of
Panchayath Presidents, Members, and Social Workers are among the events.

Pilgrims' awareness is second only to personnel and locals' awareness. Every pilgrim visiting Sabarimala should be aware of the local customs and rituals, as well as the care that need be taken by pilgrims during their journey, particularly through the forest pathways. Plastic usage was widely publicised in Sannidhanam and the adjacent districts, as well as Pampa and the ancient Forest paths leading to Sannidhanam.

\section{Actions Taken to Reduce Plastic Waste Pressure Precautionary Measures}

Installed dust bins along the traditional Forest paths to Pamba for pilgrims to dispose of garbage and set up temporary satellite stations for plastic removal on the approach route to Pampa. It has been noticed that, based on previous experience, these procedures will assist in preventing pilgrims from tossing polythene bags, bottles, and other items into the woodlands. To restrict the flow of cotton cloths and solid plastic trash used by pilgrims at Pampa, two iron nets were erected across the Pampa river at Triveni.

Forest-dependent people were actively involved in the collection of debris that had accumulated over the iron net built across the River Pampa, and the solid wastes were collected and disposed of in the Pampa temporary satellite station. Every week, the debris discharged at the Temporary Satellite Stations was divided into two categories: degraded and nondegraded.

\section{Creation of Alternative Livelihoods}

In terms of material circumstances of living, the nomadic Malapandarams are the most primitive of all the tribes. They are discovered to be extremely reliant on forest resources for their survival. During the rainy season, they reside in makeshift houses constructed of wild palm fronds, reeds, and bamboo that they move from place to place. 
Agriculturists with modest land holdings and low-skilled labour are all reliant on forests for fuel and feed.

The project's inclusion of these forest-dependent communities and VSS members as guides, garbage collectors, drivers, forest watchers, and fire monitors has expanded their participation in biodiversity protection. The initiative gave forest-dependent and forest-resource-using people the chance to participate in forest preservation and policy formation for improved livelihoods. The VSS members were directly involved in different protection-related tasks such as fire line work, afforestation, nursery care, and so on. The Pathanamthitta district administration has financed the Ranni Forest Development agency in ensuing years for employing VSS members and tribal peoples as Eco guards for cleaning operations during the Sabarimala Manadala makaravilakku Festival season after the project's successful execution.

The Vana Samrakshana Samithi (VSS) plays an important role in environmental conservation and ecotourism. The communities living near the forests under ongoing study are neither asset-rich nor self-sufficient enough to be able to rely on the forests for both their fundamental needs and income-generating activities to any significant level. Diversifying revenues away from enterprises that rely on extracting value from forest products has been made possible by other income-generating activities.

\section{Biodiversity Conservation}

Cultural diversity has a strong relationship with biodiversity, and its significance for biodiversity conservation is growing (Gadgil et al 1993; Berkes 1995; Dasman 1995; McNeely 1995; Arizpe 1996; Furze et al 1996; Liu 1996; Sinha 1996; Augustine 1999). The Article 8j of the Convention on Biological Diversity, for example, stress for "Respect, protect, and sustain knowledge, innovations, and practises of indigenous and local communities exemplifying traditional customs pertinent for the conservation and sustainable use of biological diversity, and encourage their wider application with the consent and participation of the holders of such knowledge, innovations, and practises" .The temple of Sabarimala and its environs are noteworthy in that they are located within a protected area. Forests are essential for combating global warming and constructing sustainable civilizations. Forest conservation is the activity of planting trees and maintaining forested regions for future generations' benefit and sustainability. Kerala's forest conservation and afforestation initiatives are paying off, with the state's forest cover increasing for the second consecutive assessment period. According to the India State of Forest Report, 2019, issued by the Ministry of Environment, Forests and Climate Change's Forest Survey of India, Kerala is rated third among the top five states in terms of increased forest cover. VSS play a critical role in putting ecosystem management and conservation plans into action on the ground.

\section{CONCLUSION}

Dudley et al, 2005 discovered links between religions and land and water conservation in every belief system they studied. Undoubtedly, human groups have not always protected nature, but sacred natural locations are one example of where people have done so in general. Because they are firmly ingrained in local cultural values and belief systems, many of these places have withstood environmental deterioration. They frequently serve as a haven for rare or endangered animals. The survival of a number of species is largely reliant on sacred natural places. As a result, these key locations can play an essential role in biodiversity conservation by maintaining gene pools that are required to repair damaged ecosystems. This study has shown that a socio-economic perspective must be considered alongside ecological perspective in considering future approaches 
to forest management. The livelihoods of the population in the area generally depend, in part, on forest resources. The views and needs of these communities need to be taken into account. Further to this, the communities must be integral to any successful management regime. If they do not have a sense of ownership or of benefitsharing, they will have less inclination to look after the forests.

This initiative was not the result of a "revolution," but rather of a planned social transformation based on a policy framework that will take time to fulfil its goals. Biological and cultural diversity are increasingly seen as mutually reinforcing and interconnected. As a result, cultural and biological variety work together to provide resilience in both social and ecological systems, which is a valuable advantage in an era of rapid global change. Sacred natural places are important because of their dual role in preserving cultures and protecting the environment. These locations are often rich in biodiversity because they are revered, not because of it. As a result, if properly cared for, these exceptional sites may contribute significantly to both biological variety protection and cultural identity preservation.

\section{Acknowledgement: None}

\section{Conflict of Interest: None}

\section{Source of Funding: None}

\section{REFERENCES}

1. Arizpe, L. 1996. Culture and Environment. Nature \& Resources 32 (1): 1.

2. Berkes, F. 1995. Indigenous Knowledge and Resource Management Systems: A Case Study from James Bay. In Property Right and Design Application, edited by S. Hanna and M. Munasinghe, 99-110.

3. Dasman, R. F. 1995. The Importance of Culture and Biological Diversity. In Biodiversity: Culture, Conservation and Ecodevelopment, edited by M. Oldfield and J. Alcorn. Boulder, Colorado: Westview Press, 9-15

4. Dudley, N., Higgins-Zogib L. and Mansourian, S. 2005. "Beyond Belief, Linking faiths and protected areas to support biodiversity conservation". A research report by WWF, Equilibrium and The Alliance of Religions and Conservation (ARC). Available at: http://assets.panda.org/downloads/beyond belief.pdf

5. Furze, B., T. De Lacy, and J. Brickhead. 1996. Culture, Conservation and Biodiversity. .New York: John Wiley \& Sons

6. Gadgil, M., F. Berkes and C. Folke. 1993. Indigenous Knowledge for Biodiversity Conservation. Ambio 22: 151-156.

7. Hamilton, L. S. 1993. Ethics, Religion and Biodiversity. Cambridge, England: The White Horse Press.

8. Liu Dewang. 1996. Religion: An Effective Way to Conserve Wildlife. Chinese Biodiversity 4 (2): 123-124.

9. McNeely, J. A. 1995. The Interaction between Biological Diversity and Cultural Diversity. Paper presented at the International Conference on Indigenous People, Environment and Development held in Zurich, 15-18 May.

10. McNeely, J. A.2000. Cultural Factors in Conserving Biodiversity. In Links between Culture and Biodiversity, edited by J. C. Xu. Kunming, China: Yunnan Science and Technology Press, 128-142

11. Motonaka, M. 2006. "Sacred sites and pilgrim routes in the Kii mountain range". In UNESCO, 2006, op. Cit

12. Puspa Gogoi. 1996. Plants Used in Religious Beliefs of the Tai Khamtis. In Proceedings of the Second International Congress of Ethnobiology, edited by Pei Shengji. Kunming, China: Yunnan Science and Technology Press.

13. Sinha, R. K. 1996. Conservation of Cultural Diversity of Indigenous People Essential for Protection of Biological Diversity. In Ethnobotany in Human Welfare, edited by S. K. Jain. New Delhi: Deep Publications 280-283.

14. Tiwari, B.K., Barik, S.K. and Tripathi, R.S. 1998. "Biodiversity Value, Status, 
R. Kamalahar. Participatory conservation of sacred natural sites: a study of Haritha Poonkavanam project of Sabarimala, Kerala, India.

and Strategies for Conservation of Sacred Groves of Meghalaya, India”. Ecosystem Health 4(1): 20-32.

15. Verschuuren, B., Wild, R., McNeely, J., and Oviedo, G. (2010) Sacred Natural Sites: Conserving Nature and Culture. London: Earthscan

16. Wickramsinghe, A. 2005. “Adam's Peak Sacred Mountain Forest". In UNESCO, 2003b, op. cit.
17. Wild, R. and McLeod, C. (2008) Sacred Natural Sites: Guidelines for Protected Area Managers. Gland, Switzerland \& Paris, France: IUCN and UNESCO.

How to cite this article: R. Kamalahar. Participatory conservation of sacred natural sites: a study of Haritha Poonkavanam project of Sabarimala, Kerala, India. International Journal of Research and Review. 2021; 8(10): 166-173. DOI: https://doi.org/10.52403/ijrr.20211021 